\title{
PHYTOMASS DECOMPOSITION AND NUTRIENTS RELEASE FROM PEARL MILLET, GUINEA GRASS AND PALISADE GRASS
}

\author{
TAXAS DE DECOMPOSIÇÃO E LIBERAÇÃO DE NUTRIENTES DA FITOMASSA \\ DE MILHETO, CAPIM COLONIÃO E CAPIM-BRAQUIÁRIA
}

\section{Claudio Hideo Martins da COSTA ${ }^{1}$; Carlos Alexandre Costa CRUSCIOL $^{2}$; Rogério Peres SORATTO ${ }^{2}$ Jayme FERRARI NETO $^{3}$}

1. Professor, Doutor, Universidade Federal de Goiás, Jataí, GO, Brasil - Faculdade de Ciências Agronômicas-UNESP, Botucatu, SP, Brasil. c_hideo@hotmail.com; 2. Professor, Doutor, Faculdade de Ciências Agronômicas - UNESP, Botucatu, SP, Brasil. crusciol@fca.unesp.br; 3. Doutor em Agronomia pela Faculdade de Ciências Agronômicas-UNESP, Botucatu, SP, Brasil.

\begin{abstract}
The objective of this study was to evaluate the production and persistence of biomass of pearl millet (Pennisetum glaucum), guinea grass (Panicum maximum) and palisade grass (Urochloa brizantha), as well as the release rate of macronutrients and $\mathrm{Si}$ and changes in cellulose, lignin and the $\mathrm{C} / \mathrm{N}$ and $\mathrm{C} / \mathrm{Si}$ ratios of biomass. The experimental design was a randomized block design, with four replications, in a factorial constituted by three cover crops (pearl millet, guinea grass and palisade grass) and six sampling times $(0,14,34,41,51$ and 68 days after desiccation (DAD). The pearl millet produced more biomass and accumulated more $\mathrm{N}, \mathrm{P}, \mathrm{K}, \mathrm{Ca}, \mathrm{Mg}, \mathrm{S}, \mathrm{Si}$ and $\mathrm{C}$ than the guinea grass and palisade grass. The maximum release rate of macronutrient occurred soon after the desiccation of the cover crops. The decomposition and release rate of nutrients and $\mathrm{Si}$ was higher in the biomass of pearl millet, compared to other cover crops. Over time there was an increased $\mathrm{C} / \mathrm{N}$ ratio, cellulose and lignin content and reduction in the $\mathrm{C} / \mathrm{Si}$ and decomposition rate of the biomass. The $\mathrm{K}$ is the nutrient most quickly available to the soil, and $\mathrm{Si}$ has the lowest release rate. Plants with higher biomass production and lower $\mathrm{C} / \mathrm{Si}$ are more interesting to be used under no-till by offering greater and more persistent ground cover.
\end{abstract}

PALAVRAS-CHAVE: Pennisetum glaucum. Panicum maximum. Urochloa brizantha. Straw persistence. Nutrients recycling.

\section{INTRODUCTION}

For the implementation and maintenance of no-tillage system should be used cover crops to keep the soil surface permanently covered with biomass and are also able to recycle nutrients and make them available gradually to crops in sucession. The persistence of biomass on the ground, ability to recycle nutrients, mobilization leachate or poorly soluble elements and the release of these for subsequent crop are important indicators of the quality of cover crops (BOER et al., 2007; 2008; CRUSCIOL; SORATTO , 2007; CRUSCIOL et al., 2008; LEITE et al., 2010).

In Brazilian regions of grain production, characterized as dry winter, the pearl millet (Pennisetum glaucum (L.) R. Brown), among other grasses, has been the main species used as cover crop in crop rotation system (BOER et al, 2007), once this plant is characterized by high production of biomass, greater than $13 \mathrm{Mg} \mathrm{ha}^{-1}$ (CRUSCIOL; SORATTO, 2009; Soratto et al., 2012), persistence on the ground after killed (SILVA et al., 2006), high capacity of soil nutrient extraction, with broad benefits of recycling nutrients, especially $\mathrm{N}$ and $\mathrm{K}$, reducing the risk of leaching losses (CRUSCIOL;SORATTO, 2009).
However, in recent years it has also increased planting forages as Urochloa and Panicum in these grain-producing regions, and is mainly due to the adoption of new areas to the integration of crop-livestock. The rotation of an annual crop and pasture provides mutual benefits for crop and grazing, such as reducing the incidence of weeds and breaking the cycle of pests and diseases, resulting in increased productivity (VILELA et al., 2011). The Panicum maximum and Urochloa brizantha are species with wide adaptability by having strong and deep root system, able to exploit higher volume of soil, so have high drought tolerance and absorption of nutrients in deeper soil layers, can achieve productivity higher than $6 \mathrm{Mg}$ ha $^{-1}$ (CRUSCIOL; SORATTO, 2007; NUNES et al., 2006), featuring such species as of excellent quality for ground cover in no-tillage system (BARDUCCI et al., 2009). In addition, they increase soil biological activity, favor the increase in organic matter content and reduce erosion (VILELA et al., 2011).

Thus, in the different types of crop production systems the residue decomposition is an important variable in nutrient cycling. Therefore, it is crucial to understand the dynamics of nutrient release from biomass cultivated species prior to 
commercial crop so that one can reconcile this aspect with the greatest persistence of crop residues on the soil surface (Boer et al., 2007), facilitating the planning of production systems.

The objective of this study was to evaluate the production and persistence of biomass of pearl millet, guinea grass and palisade grass, as well as the release rate of macronutrients and $\mathrm{Si}$ and changes in cellulose, lignin and the $\mathrm{C} / \mathrm{N}$ and $\mathrm{C} / \mathrm{Si}$ ratios of biomass.

\section{MATERIAL AND METHODS}

This study was developed at the Lageado Experimental Farm, Botucatu, São Paulo, Brazil $\left(22^{\circ} 58^{\prime} \mathrm{S}, 48^{\circ} 23^{\prime} \mathrm{W}\right.$ and $765 \mathrm{~m}$ altitude). Soil at the location is a Red Nitosol. The chemical characteristics of the soil $(0-20 \mathrm{~cm})$ were determined before setting up the experiment, and the results were: $33.3 \mathrm{~g} \mathrm{dm}^{-3}$ of organic matter, $\mathrm{pH}$ $\left(\mathrm{CaCl}_{2}\right)$ 5.0, $12.0 \mathrm{mg} \mathrm{dm}^{-3}$ of $\mathrm{P}$ (resin); 1.4, 31.0, 12.6, $51.3 \mathrm{mmol}_{\mathrm{c}} \mathrm{dm}^{-3}$ of $\mathrm{K}, \mathrm{Ca}, \mathrm{Mg}$ and $\mathrm{H}+\mathrm{Al}$, respectively, and $47 \%$ of base saturation.

According to the Köppen climate classification, the predominant climate in the region is the Cwa, i.e., a higher altitude tropical climate with a dry winter and hot, wet summer. During the experiment the precipitation and monthly mean temperature in 2003 and 2004 were, respectively, $173 \mathrm{~mm}$ and $23.1{ }^{\circ} \mathrm{C}$ in November, $184 \mathrm{~mm}$ and $23.5{ }^{\circ} \mathrm{C}$ in December, $302 \mathrm{~mm}$ and $22.5{ }^{\circ} \mathrm{C}$ in January, $162 \mathrm{~mm}$ and $23.1^{\circ} \mathrm{C}$ in February, $122 \mathrm{~mm}$ and $22.3 \mathrm{C}$ in March and $114 \mathrm{~mm}$ and $22.0^{\circ} \mathrm{C}$ in April.

A randomized block experimental design was used with four replications in a $3 \times 6$ factorial arrangement, consisting of three plant covers (pearl millet, guinea grass and palisade grass) and six periods of shoot dry matter collection $[0,14,34,41$, 51 and 68 days after desiccation (DAD)]. The plots size were $50 \mathrm{~m}^{2}$ ( $5 \mathrm{~m}$ width, $10 \mathrm{~m}$ length).

The cover species were sown on November 08, 2003, and seedlings emerged twelve days later November 20, 2003. A seed quantity of 20, 18 and $15 \mathrm{~kg} \mathrm{ha}^{-1}$ of Pennisetum glaucum cv. BN2, Panicum maximum cv. Mombaça and Urochloa brizantha cv. Marandu, respectively, with a spacing of $0.17 \mathrm{~m}$ between rows and a depth of approximately $0.03 \mathrm{~m}$. At 75 day after emergence (DAE), on February 03, 2004, the desiccation with herbicide application was performed with glyphosate $\left(1,920 \mathrm{~g} \mathrm{ha}^{-1}\right.$ a.i. $)$.

The plant shoots were collected on $02 / 03 / 2004$ (the day of desiccation - 0 DAD), on 02/17/2004 (14 DAD), on 03/08/2004 (34 DAD), on
03/15/2004 (41 DAD), on 03/25/2004 (51 DAD) and 04/11/2004 (68 DAD). Three sub-samples per plot were taken on each date according to the method proposed by Crusciol et al. (2005), from an internal area of $0.25 \mathrm{~m}^{2}$, constituting one composite sample per plot. Within the experimental units, sampling was performed at random points along diagonal crosswise lines, excluding $0.50 \mathrm{~m}$ at either end (border).

The samples were placed in paper bags and dried in a forced air circulation oven at $60{ }^{\circ} \mathrm{C}$ to constant weight and then weighed for determination of shoot dry matter. The material was ground in a Willey mill for determination of the levels of macronutrients (MALAVOLTA et al., 1997), carbon (TEDESCO et al., 1995), silicon (KORNDÖRFER et al., 2002), lignin and cellulose (VAN SOEST, 1963).

The amount of macronutrients, $\mathrm{C}$ and $\mathrm{Si}$ in the shoot dry matter was determined multiplying the amount of shoot dry matter by the concentration of the elements of the plant residue of each sampling. With these values, the degradation of shoot dry matter and the content of elements contained in it were calculated, and the data were expressed in $\mathrm{Mg}$ $\mathrm{ha}^{-1}$ or kg ha ${ }^{-1}$, repectively.

To describe shoot dry matter decomposition and the remaining content of the elements $(\mathrm{N}, \mathrm{P}, \mathrm{K}$, $\mathrm{Ca}, \mathrm{Mg}, \mathrm{S}, \mathrm{C}$, and $\mathrm{Si}$ ) in $\mathrm{kg} \mathrm{ha}^{-1}$ the exponential mathematical model described by Thomas and Asakawa (1993) of the $X=X_{o} e^{-k t}$ type was used, in which $\mathrm{X}$ is the content of shoot dry matter or of elements remaining after a period of time $t$, in days; $X_{o}$ is the initial quantity of shoot dry matter or of elements; and $\mathrm{k}$ is the constant of residue decomposition or release of elements. With the $\mathrm{k}$ value, the half-life time was calculated $\left(\mathrm{t}^{1} / 2=\right.$ 0.693/k) (PAUL; CLARK, 1989), which expresses the period of time necessary for half of the plant residue to decompose or for half the elements contained in the shoot dry matter to be released. Applying the first derivative to the functions fitted to the data on shoot dry matter and content release of the elements, the daily rates of shoot dry matter decomposition and release of elements after cover crop desiccation were calculated and ajusted to a mathematical function (ROSOLEM et al., 2003).

The mean values of the treatments of the factor plant cover were compared by the LSD test at $5 \%$ and the other data from the factor shoot dry matter were fitted to mathematical functions at $5 \%$. For the correlation analysis was adopted Pearson's method, applied to $\mathrm{C} / \mathrm{N}$ ratio, lignin, cellulose, nutrients contents and nutrients amount with plant cover species. 


\section{RESULTS AND DISCUSSION}

The amount of pearl millet MS was higher, reached at the time of desiccation $14.093 \mathrm{Mg} \mathrm{ha}^{-1}$, while the guinea grass and palisade grass produced, respectively, 6.402 and $5.599 \mathrm{Mg} \mathrm{ha}^{-1}$ (Table 1 and Figure 1A). This result is mainly due to the rapid growth of pearl millet, which had already reached the maximum production at $75 \mathrm{DAE}$, while in guinea grass and palisade grass the maximum dry matter production occurs between 110 and $130 \mathrm{DAE}$ (ROSA et al., 2004, 2007). Therefore, it is probable that in a longer period the palisade grass and guinea grass will produce higher amount of dry matter in relation to pearl millet.

Crusciol and Soratto (2009) and Soratto et al. (2012) found similar dry matter production of pearl millet, thereabout 14.800 and $14.040 \mathrm{Mg} \mathrm{ha}^{-1}$, when killed at 90 and 75 DAE, respectively, in the same region. Nunes et al. (2006) found dry matter production values of palisade grass and guinea grass similar to this work, in Diamantina (MG), with the same cultivar, however, with a longer growing time.

Table 1. Analysis of variance for variables related to the amount of dry matter (DM), C/N ratio, cellulose, lignin, nutrient content and remaining amount of nutrients as a function of straw cover species (C) and days after desiccation (D) and correlation coefficients between remaining amounts of dry mass of straws of pearl millet (PM), palisade grass (PG) and guinea grass (GG) with some characteristics of crop residues over time.

\begin{tabular}{|c|c|c|c|c|c|c|c|c|c|}
\hline \multirow{2}{*}{ Variable } & \multirow{2}{*}{ PM } & \multirow{2}{*}{ PG } & \multirow{2}{*}{ GG } & \multicolumn{3}{|c|}{ F Probability } & \multicolumn{3}{|c|}{ Correlation with DM } \\
\hline & & & & $\mathrm{C}$ & $\mathrm{D}$ & $\mathrm{C} \times \mathrm{D}$ & PM & PG & GG \\
\hline & \multicolumn{9}{|c|}{----- $\left(\mathrm{Mg} \mathrm{ha}^{-1}\right)$---- } \\
\hline $\mathrm{DM}$ & $8.7 \mathrm{a}$ & $4.7 \mathrm{~b}$ & $4.9 \mathrm{~b}$ & $<0.001$ & $<0.001$ & $<0.001$ & - & - & - \\
\hline $\mathrm{C} / \mathrm{N}$ ratio & $45 \mathrm{a}$ & $30.4 \mathrm{~b}$ & $30.7 \mathrm{~b}$ & $<0.001$ & $<0.001$ & $<0.001$ & $-0.772 * *$ & $-0.569 * *$ & $-0.663^{* *}$ \\
\hline \multirow[t]{2}{*}{$\mathrm{C} / \mathrm{Si}$} & $33 \mathrm{a}$ & $27.1 \mathrm{~b}$ & $24.5 \mathrm{~b}$ & $<0.001$ & $<0.001$ & 0.023 & $0.651 * *$ & $0.748 * *$ & $0.941 * *$ \\
\hline & \multicolumn{9}{|c|}{----- $\left(\mathrm{g} \mathrm{kg}^{-1}\right)$------ } \\
\hline Cellulose & $401 \mathrm{a}$ & $354 \mathrm{~b}$ & 294 c & $<0.001$ & $<0.001$ & 0.003 & $-0.480^{*}$ & $-0.721 * *$ & $-0.913 * *$ \\
\hline Lignin & $33 \mathrm{~b}$ & $36.6 \mathrm{a}$ & $29.7 \mathrm{~b}$ & $<0.001$ & 0.019 & 0.934 & $-0.565 * *$ & $-0.084 \mathrm{~ns}$ & $-0.425^{*}$ \\
\hline $\mathrm{N}$ content & $10.8 \mathrm{~b}$ & $14.1 \mathrm{a}$ & $13.9 \mathrm{a}$ & $<0.001$ & $<0.001$ & 0.641 & $0.588^{* *}$ & $0.628 * *$ & $0.805^{* *}$ \\
\hline $\mathrm{P}$ content & $0.7 \mathrm{~b}$ & $0.97 \mathrm{a}$ & $0.87 \mathrm{a}$ & $<0.001$ & $<0.001$ & $<0.001$ & $0.754 * *$ & $0.516^{*}$ & $0.797 * *$ \\
\hline $\mathrm{K}$ content & $5.9 \mathrm{~b}$ & $7.9 \mathrm{a}$ & $8.2 \mathrm{a}$ & $<0.001$ & $<0.001$ & $<0.001$ & $0.889 * *$ & $0.679 * *$ & $0.859 * *$ \\
\hline Ca content & $4.2 \mathrm{c}$ & $5.1 \mathrm{~b}$ & $5.9 \mathrm{a}$ & $<0.001$ & $<0.001$ & 0.587 & $0.815^{* *}$ & $0.489^{*}$ & $0.748 * *$ \\
\hline $\mathrm{Mg}$ content & $2.2 \mathrm{c}$ & $3.1 \mathrm{~b}$ & $3.9 \mathrm{a}$ & $<0.001$ & $<0.001$ & 0.588 & $0.815^{* *}$ & $0.487^{*}$ & $0.748 * *$ \\
\hline S content & $3.1 \mathrm{c}$ & $4.1 \mathrm{~b}$ & $4.8 \mathrm{a}$ & $<0.001$ & $<0.001$ & $<0.001$ & $0.920 * *$ & $0.864 * *$ & $0.843 * *$ \\
\hline $\mathrm{C}$ content & $452 \mathrm{a}$ & $418 \mathrm{~b}$ & $415 \mathrm{~b}$ & $<0.001$ & $<0.001$ & 0.184 & $0.666 * *$ & $0.597 * *$ & $0.689 * *$ \\
\hline \multirow[t]{2}{*}{ Si content } & $12.9 \mathrm{c}$ & $15.8 \mathrm{~b}$ & $17.5 \mathrm{a}$ & $<0.001$ & $<0.001$ & 0.017 & $-0.666 * *$ & $-0.843 * *$ & $-0.943 * *$ \\
\hline & \multicolumn{9}{|c|}{----- $\left(\mathrm{kg} \mathrm{ha}^{-1}\right)$----- } \\
\hline $\mathrm{N}$ amount & $103 \mathrm{a}$ & $68 \mathrm{~b}$ & $71 \mathrm{~b}$ & $<0.001$ & $<0.001$ & $<0.001$ & $0.819 * *$ & $0.917 * *$ & $0.948 * *$ \\
\hline P amount & $7.7 \mathrm{a}$ & $4.9 \mathrm{~b}$ & $4.9 \mathrm{~b}$ & $<0.001$ & $<0.001$ & $<0.001$ & $0.951 * *$ & $0.704 * *$ & $0.901 * *$ \\
\hline $\mathrm{K}$ amount & $66 \mathrm{a}$ & $41 \mathrm{~b}$ & $46 \mathrm{~b}$ & $<0.001$ & $<0.001$ & $<0.001$ & $0.959 * *$ & $0.827 * *$ & $0.908 * *$ \\
\hline $\mathrm{Ca}$ amount & $39 \mathrm{a}$ & $24 \mathrm{c}$ & $30 \mathrm{~b}$ & $<0.001$ & $<0.001$ & $<0.001$ & $0.983 * *$ & $0.826^{* *}$ & $0.961 * *$ \\
\hline
\end{tabular}


Phytomass decomposition and nutrients...

COSTA, C. H. M. et al.

\begin{tabular}{llllllllll}
\hline Mg amount & $21 \mathrm{a}$ & $15 \mathrm{~b}$ & $20 \mathrm{a}$ & $<0.001$ & $<0.001$ & $<0.001$ & $0.964 * *$ & $0.725^{* *}$ & $0.940^{* *}$ \\
S amount & $34 \mathrm{a}$ & $22 \mathrm{c}$ & $26 \mathrm{~b}$ & $<0.001$ & $<0.001$ & $<0.001$ & $0.949^{* *}$ & $0.913^{* *}$ & $0.882^{* *}$ \\
$\mathrm{C}$ amount & $3982 \mathrm{a}$ & $1982 \mathrm{~b}$ & $2062 \mathrm{~b}$ & $<0.001$ & $<0.001$ & $<0.001$ & $0.997 * *$ & $0.991^{* *}$ & $0.981^{* *}$ \\
Si amount & $105 \mathrm{a}$ & $73 \mathrm{c}$ & $84 \mathrm{~b}$ & $<0.001$ & $<0.001$ & $<0.001$ & $0.844^{* *}$ & $0.662^{* *}$ & $0.747^{* *}$
\end{tabular}

ns: not significant: $* p \leq 0.05 ; * * p \leq 0.01$.

For pearl millet and guinea grass, the dry matter yield was greater than $6.000 \mathrm{Mg} \mathrm{ha}^{-1}$, and palisade grass was close to this value, as per Alvarenga et al. (2001) is considered the ideal minimum amount of addition of dry matter in a crop rotation system, in order to maintain adequate ground coverage. The high dry matter production of cover crops was related to the growing season, since during the cycle of these plants it happened a regular rainfall.
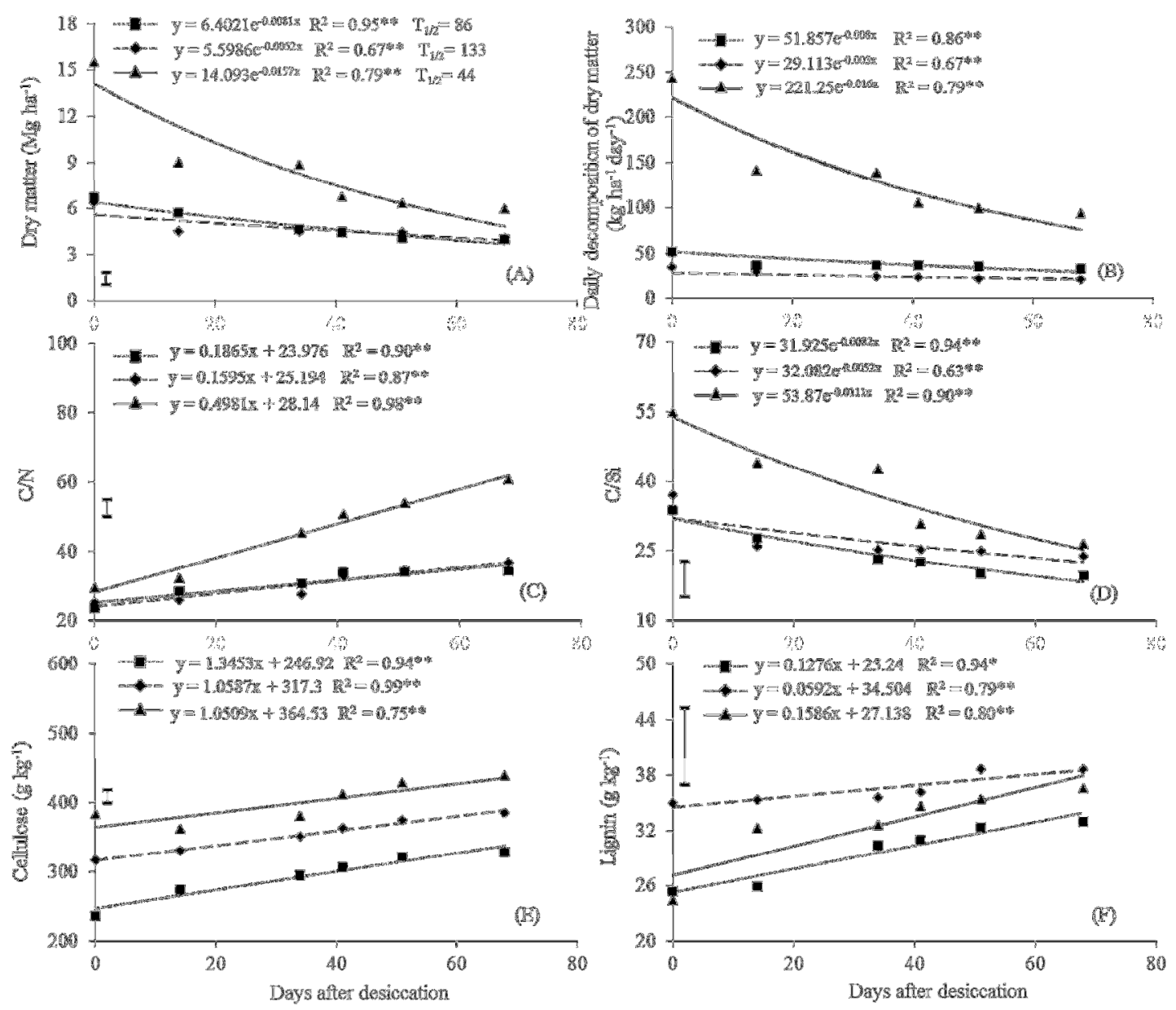

Figure 1. Dry matter (A), daily decomposition of dry matter (B), C/N ratio(C), C/Si ratio (D), cellulose (E) and lignin $(\mathrm{F})$ of straws of pearl millet $(\boldsymbol{\Delta})$, palisade grass $(\boldsymbol{})$ and guinea grass $(\boldsymbol{\nabla})$, as a function of time after desiccation. ** Significant at $1 \%$ of probability by $\mathrm{F}$ test. Vertical bars are indicative of the MSD value at $5 \%$ probability. $\mathrm{T}_{1 / 2}$ refers to half life time in DAD.

The highest rates of biomass decomposition occurred in the periods of $0-14 \mathrm{DAD}$, reaching on average values of 213,53 and $30 \mathrm{~kg} \mathrm{ha}^{-1}$ per day for the pearl millet, guinea grass and palisade grass, respectively (Figure 1B). This rapid decomposition can be attributed to the high average temperature and the occurrence of precipitation after desiccation, which accelerate the decomposition of plant residues (BOER et al, 2008;. LEITE et al., 2010). These results are contrasted to those of Torres et al. (2008) and Leite et al. (2010), who observed halflife at 131 and 100 days after management for 
biomass of pearl millet and palisade grass, respectively. However, the environmental conditions and the management adopted in the work were differents, demonstrating the importance of these factors in the decomposition of plant biomass.

The most intense decomposition of residue of pearl millet by the microorganisms in the initial stage possibly due to the higher concentration of cellulose, which at the time of desiccation was $365 \mathrm{~g}$ $\mathrm{kg}^{-1}$, while of the palisade grass and guinea grass was 322 and $257 \mathrm{~g} \mathrm{~kg}^{-1}$, respectively (Figure 1E). Cellulose is a component of less resistant residues, which favors oxidation chemistry and biochemistry leading to significant reduction of the material (PEGADO et al., 2008). Other factors may also have influenced, like the high $\mathrm{C} / \mathrm{Si}$ ratio (Figure 1D) and the high percentage of initial control of pearl millet by desiccation with glyphosate (MONQUERO et al., 2010). The $\mathrm{Si}$ is a compound recalcitrant to microbial attack, where its lower concentration favors decomposition.

In the period 51-68 DAD, the decomposition rate of pearl millet reduced $121 \mathrm{~kg}$ $\mathrm{ha}^{-1}$ per day compared to 0-14 DAD (Figure 1B), remaining $4.845 \mathrm{Mg} \mathrm{ha}^{-1}$, to the point that, the values in the latest evaluation were similar to those observed for palisade grass and guinea grass, of 3.691 and $3.931 \mathrm{Mg} \mathrm{ha}^{-1}$, respectively (Figure 1A). These results can be attributed to the greater increase in $\mathrm{C} / \mathrm{N}$ ratio and reduction of $\mathrm{C} / \mathrm{Si}$ ratio over time in pearl millet compared to palisade grass and guinea grass (Figure 1C and 1D), indicating the presence of most recalcitrant compounds in the last two species.

As to the lignin content, on average there was higher contents in palisade grass followed by pearl millet and signal grass, but there was no interaction between the cover crops and days after desiccation (Table 1 and Figure 1F). However, it should be noted that the parameters showed high correlation with the dry matter (Table 1). These results show that these parameters $(\mathrm{C} / \mathrm{N}, \mathrm{C} / \mathrm{Si}$ and cellulose) are good indicators of the decomposition rate of crop residues, if analyzed together.

Regarding to the contents of the elements in cover crops shoots (Figure 2), it was found that, in general, the pearl millet had the lowest concentrations than the other species on average, except for $\mathrm{C}$, which was higher (Table 1).

The lower concentration of nutrients in pearl millet may be related to the dilution effect since the pearl millet has produced a larger amount of shoot dry matter (Figure 1A), or to the phenological stage of the plants, once, during desiccation, the pearl millet was in the milky grain stage, and the other species in the vegetative phase. Reinforcing this statement, similar result was observed by Crusciol and Soratto (2007) in the pearl millet cultivated from November to January in a red Latosol, in the same region, and managed at 71 DAE, which found lower concentrations of N, P, K, $\mathrm{Ca}$ and $\mathrm{Mg}$ in the biomass of pearl millet, compared with the other species studied. Another relevant fact is that the maximum accumulation of nutrients in pearl millet occurs at 52-55 DAE, with subsequent decay, and palisade grass and guinea grass showed increase in contents until later times (BRAZ et al., 2004).

The levels of all macronutrients have declined over time, following the results of biomass (Figures 1A and 2), except for the Si. This statement is based by the high correlation between the dry matter and nutrient content (Table 1). So, as the biomass has deteriorated, has increased the silicon concentration in plant residue after 68 DAD in about $28 \%, 52 \%$ and $20 \%$ in biomass of palisade grass, guinea grass and pearl millet, respectively (Figure $2 \mathrm{H})$ because the elements more soluble were released, leaving the Si compounds that have lower solubility (FERNANDEZ et al., 2009).

Among all the nutrients, it was found that the $\mathrm{P}, \mathrm{K}$ and $\mathrm{S}$ were released quickly at first, with further reduction, probably due to the low amount remaining in the plant tissue (Figures $2 \mathrm{~B}, 2 \mathrm{C}$ and $2 \mathrm{~F})$. Thus, in the period 0-14 DAD the $\mathrm{P}$ content reduced by $32 \%, 33 \%$ and $29 \%$, the $\mathrm{K}$ content by $38 \%, 34 \%$ and $39 \%$ and the $\mathrm{S}$ content by $44 \%, 32 \%$ and $35 \%$ of the initial amount of palisade grass, guinea grass and pearl millet, respectively. The fast $\mathrm{K}$ release rate was also observed by several authors in several plant species (COSTA et al, 2012; SORATTO et al., 2012;. FERRARI NETO et al., 2012). The $\mathrm{K}$ is an element that is not associated with any structural component of plant tissue (MARSCHNER, 2012), facilitating its initial release from the biomass. This element is not metabolized in the plant, forming connections with organic complex of easy reversibility (ROSOLEM et al., 2003). Thus, as long as the plant shoots starts the drying process and degrades, the concentration of this nutrient decreases dramatically, intensified by rainwater, after the breakup of plasma membranes (MALAVOLTA et al., 1997). 

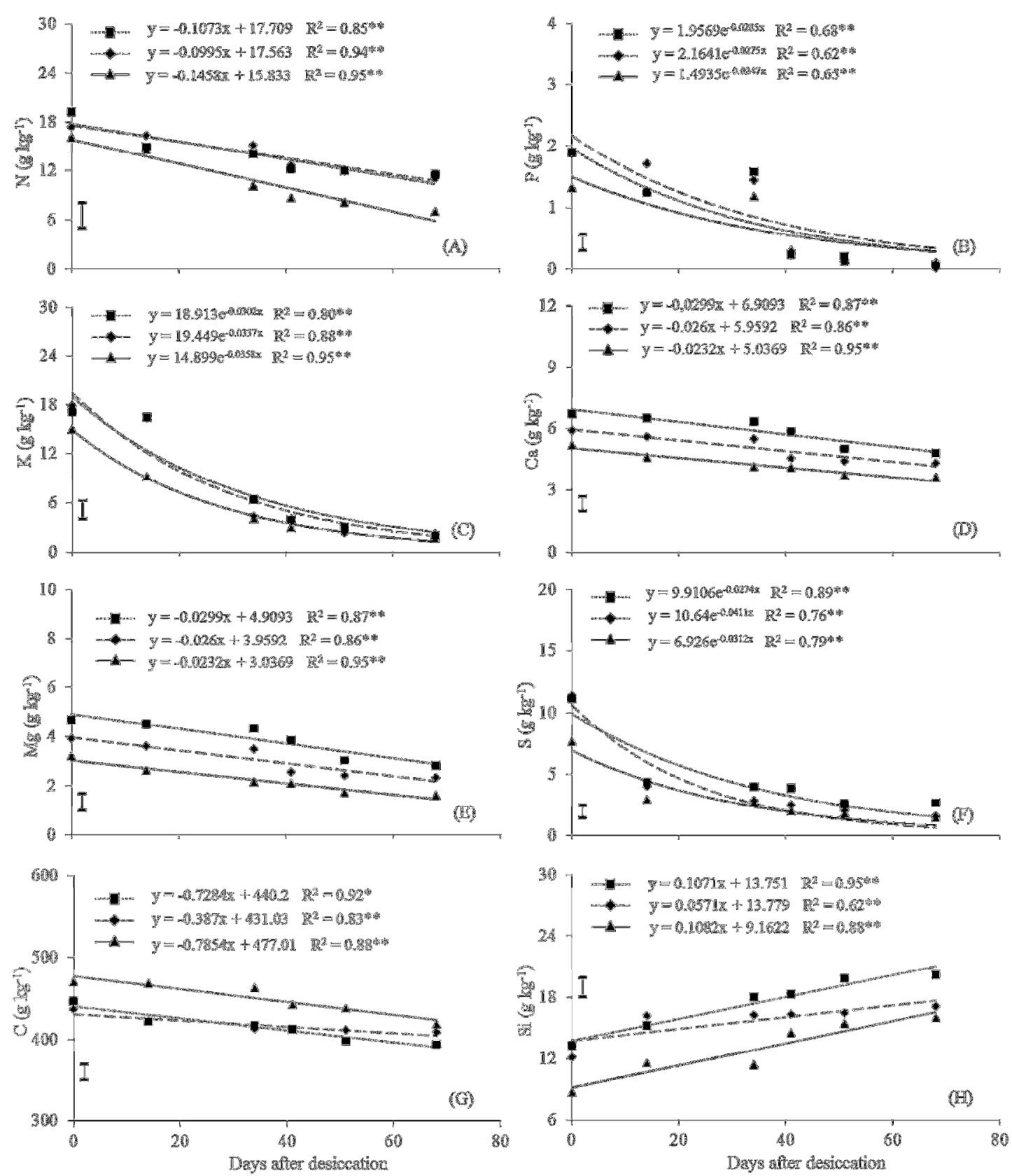

Figure 2. Contents of $\mathrm{N}(\mathrm{A}), \mathrm{P}(\mathrm{B}), \mathrm{K}(\mathrm{C}), \mathrm{Ca}(\mathrm{D}), \mathrm{Mg}(\mathrm{E}), \mathrm{S}(\mathrm{F}), \mathrm{C}(\mathrm{G})$ and $\mathrm{Si}(\mathrm{H})$ of straws of pearl millet $(\boldsymbol{\Lambda})$, palisade grass $(\bullet)$ and guinea grass $(\mathbf{\bullet})$, as a function of time after desiccation. $* * \mathrm{e} *$, significant at $1 \%$ and $5 \%$ of probability by $\mathrm{F}$ test, respectively. Vertical bars are indicative of the MSD value at $5 \%$ probability.

The pearl millet stood out to accumulate the highest amount of all nutrients (Figure 3), showing the aforementioned dilution effect. The pearl millet, being a kind of quick growth and short cycle, is able to extract considerable amounts of nutrients in a short time (CRUSCIOL; SORATTO, 2009). Otherwise the guinea grass and palisade grass, in general, accumulated similar amounts of nutrients, and in reasonable amounts. Thus, the cumulative amounts of $\mathrm{N}, \mathrm{P}, \mathrm{K}, \mathrm{Ca}, \mathrm{Mg}, \mathrm{S}, \mathrm{C}$ and $\mathrm{Si}$ were respectively of $235,21,222,74,47,115,6,713$ and $125 \mathrm{~kg} \mathrm{ha}^{-1}$ for pearl millet, 103, 13, 117, 35, 23, 70, $70,2,496$ and $77 \mathrm{~kg} \mathrm{ha}^{-1}$ for palisade grass, 122, 13, $122,45,32,69,2,891$ and $89 \mathrm{~kg} \mathrm{ha}^{-1}$ for guinea grass (Figure 3).

The larger the difference between the amount accumulated and the remaining nutrients, the greater was their quantity available to the soil. Thus, until the last evaluation, the pearl millet released the largest amounts of nutrients to the soil, 
followed by guinea grass and palisade grass. Thus, in the last evaluation had been made available by pearl millet, 207, 19, 219, 59, 37, 115, 4670 and 30 $\mathrm{kg} \mathrm{ha}^{-1}$, by the guinea grass $86,12,112,27,21,66$,
1485 and $10 \mathrm{~kg} \mathrm{ha}^{-1}$ and by the palisade grass 62 , $11,111,19,15,69,945$ and $6 \mathrm{~kg} \mathrm{ha}^{-1}$ for $\mathrm{N}, \mathrm{P}, \mathrm{K}$, $\mathrm{Ca}, \mathrm{Mg}, \mathrm{S}, \mathrm{C}$ and $\mathrm{Si}$, respectively (Figure 3).
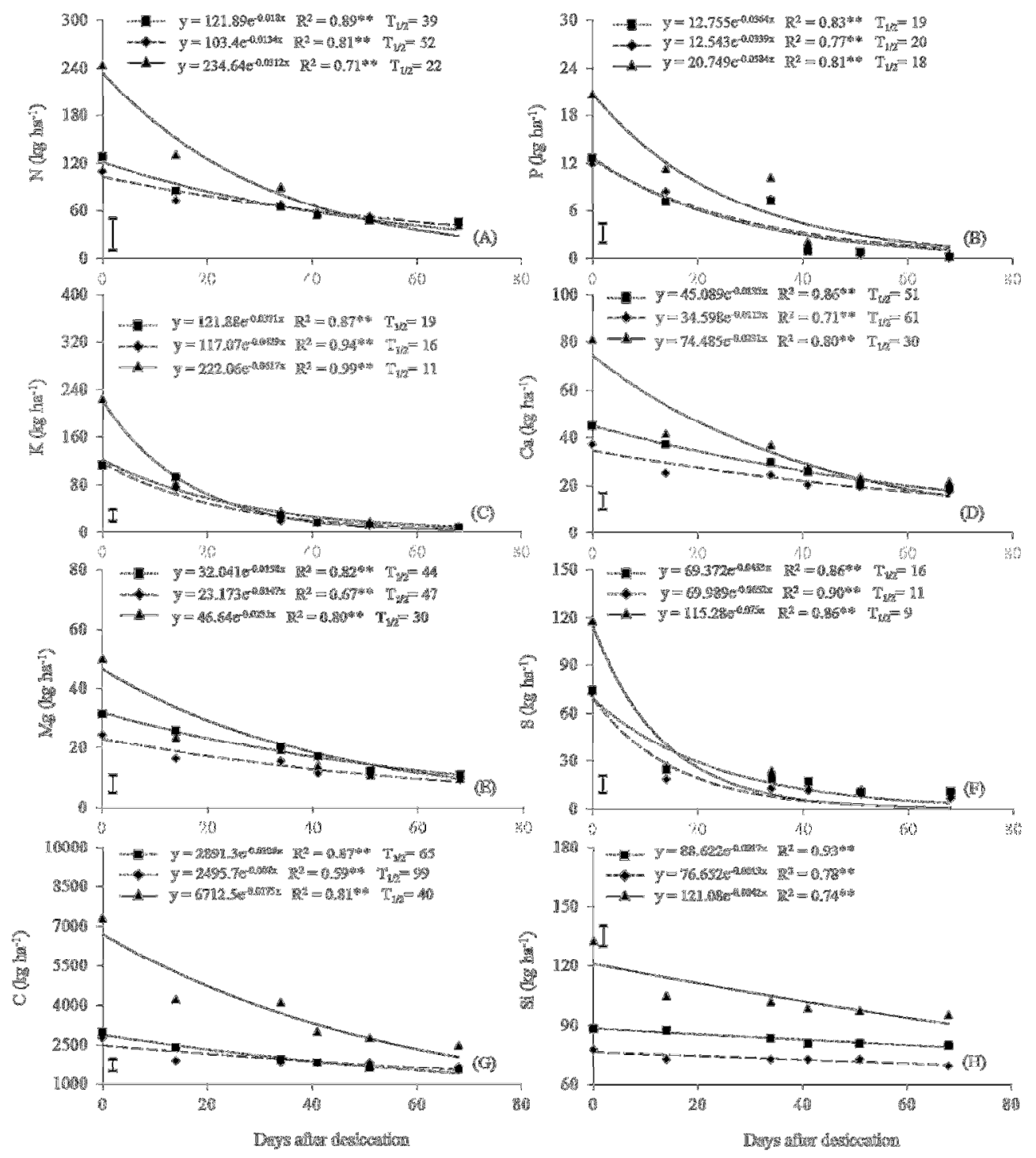

Figure 3. Remaining amount of $\mathrm{N}(\mathrm{A}), \mathrm{P}(\mathrm{B}), \mathrm{K}(\mathrm{C}), \mathrm{Ca}(\mathrm{D}), \mathrm{Mg}(\mathrm{E}), \mathrm{S}(\mathrm{F}), \mathrm{C}(\mathrm{G})$ and $\mathrm{Si}(\mathrm{H})$ of straws of pearl millet $(\mathbf{\Delta})$, palisade grass $(\bullet)$ and guinea grass $(\mathbf{\bullet})$, as a function of time after desiccation. $* *$ Significant at $1 \%$ of probability by $\mathrm{F}$ test. $\mathrm{T}_{1 / 2}$ refers to the half life time in DAD. Vertical bars are indicative of the MSD value at 5\% probability.

Soratto et al. (2012) also observed, for pearl millet at 91 days after management, and Bernardes et al. (2010) for guinea grass and palisade grass at 75 days after management, large amounts of $\mathrm{N}, \mathrm{P}$, $\mathrm{K}, \mathrm{Ca}$ and $\mathrm{Mg}$ available to the soil. These authors stated that were released by pearl millet about 243 , $37,321,52$ and $39 \mathrm{~kg} \mathrm{ha}^{-1}$, by the guinea grass about $146,20,80,64$ and $33 \mathrm{~kg} \mathrm{ha}^{-1}$ and by the palisade grass about $89,19,47,53$ and $39 \mathrm{~kg} \mathrm{ha}^{-1}$, respectively, $\mathrm{N}, \mathrm{P}, \mathrm{K}, \mathrm{Ca}$ and $\mathrm{Mg}$.
Thus, these significant amounts of nutrients released into the soil, could meet the needs of crops in succession, because $50 \%$ of total amounts of $\mathrm{N}$, $\mathrm{P}, \mathrm{K}, \mathrm{Ca}, \mathrm{Mg}$ and $\mathrm{S}$ accumulated in the biomass were released to the soil by pearl millet up to 22,18 , $11,30,30$ and $9 \mathrm{DAD}$, by the guinea grass to 39,19 , $19,51,44$ and $16 \mathrm{DAD}$, and by the palisade grass to 52, 20, 16, 61, 47 and 11 DAD, respectively (Figure 4). Soratto et al. (2012) studying the biomass decomposition of pearl millet, and Bernardes et al. (2010) the palisade grass and guinea grass, verified 
half-life times similar to pearl millet and higher for the other two species. The edaphoclimatic conditions during the decompostion of pearl millet were similar to this study, therefore, the lowest release rate of nutrients observed for the guinea grass and for the palisade grass by the authors may be related to lower rain index after management of cover crops, factor which acts directly on the
COSTA, C. H. M. et al.

decomposition (BOER et al, 2008;. LEITE et al., 2010). So, at 68 DAD it has been provided amounts of nutrients $\mathrm{N}, \mathrm{P}$ and $\mathrm{K}$ equivalent to 470, 238 and $453 \mathrm{~kg} \mathrm{ha}^{-1}$ by pearl millet, 195,150 and $232 \mathrm{~kg} \mathrm{ha}^{-1}$ by guinea grass, and 141,138 and $230 \mathrm{~kg} \mathrm{ha}^{-1}$ by palisade grass, from the fertilizers urea, superphosphate and potassium chloride, respectively.
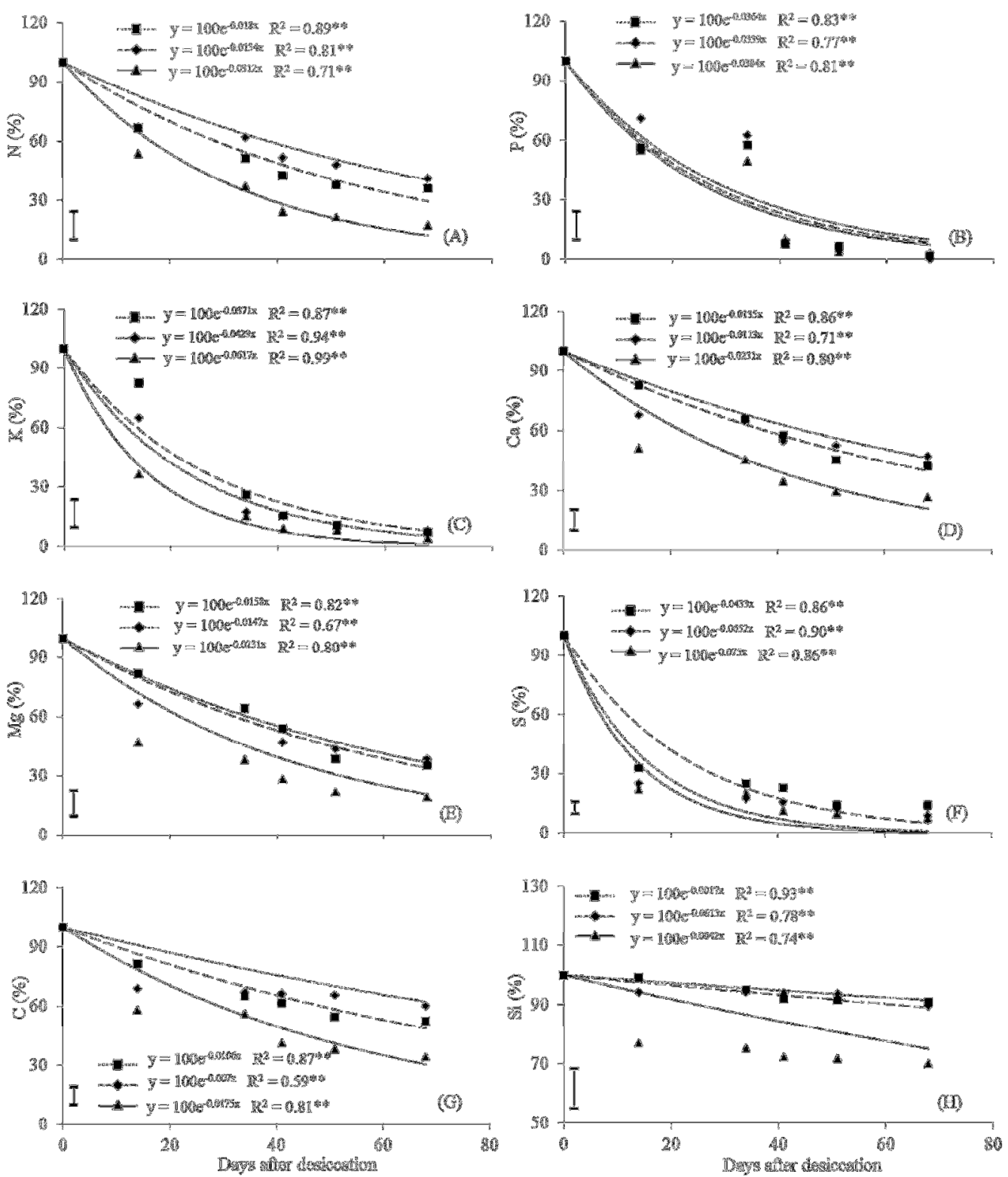

Figure 4. Percentage of remaining amount of $\mathrm{N}(\mathrm{A}), \mathrm{P}(\mathrm{B}), \mathrm{K}(\mathrm{C}), \mathrm{Ca}(\mathrm{D}), \mathrm{Mg}(\mathrm{E}), \mathrm{S}(\mathrm{F}), \mathrm{C}(\mathrm{G})$ and $\mathrm{Si}(\mathrm{H})$ of straws of pearl millet $(\mathbf{\Delta})$, palisade grass $(\bullet)$ and guinea grass $(\mathbf{\bullet})$, as a function of time after desiccation. ** Significant at $1 \%$ of probability by $\mathrm{F}$ test. Vertical bars are indicative of the MSD value at $5 \%$ probability.

It is noted that the greatest release rate of the elements $\mathrm{N}, \mathrm{P}, \mathrm{K}, \mathrm{Ca}, \mathrm{Mg}, \mathrm{S}$ and $\mathrm{C}$ occurred between 0 and 14 DAD (Figure 5). Therefore, the release of these elements occurs more quickly at the stage immediately after desiccation, with a continuous reduction, and posterior trend to stabilize at values close to zero. Crusciol et al. (2008) evaluating the rate of release of nutrients 
from oats, observed a higher rate between 10 and 20 days after management, for the nutrients $\mathrm{N}, \mathrm{K}$, $\mathrm{Ca}$ and $\mathrm{Mg}$. These authors cultivated oats in the period from July to September in an Red Latossol, so it is important to note that despite the edaphoclimatic conditions be different of this study, most of the nutrient release rate ocurred in the first 20 days after management.
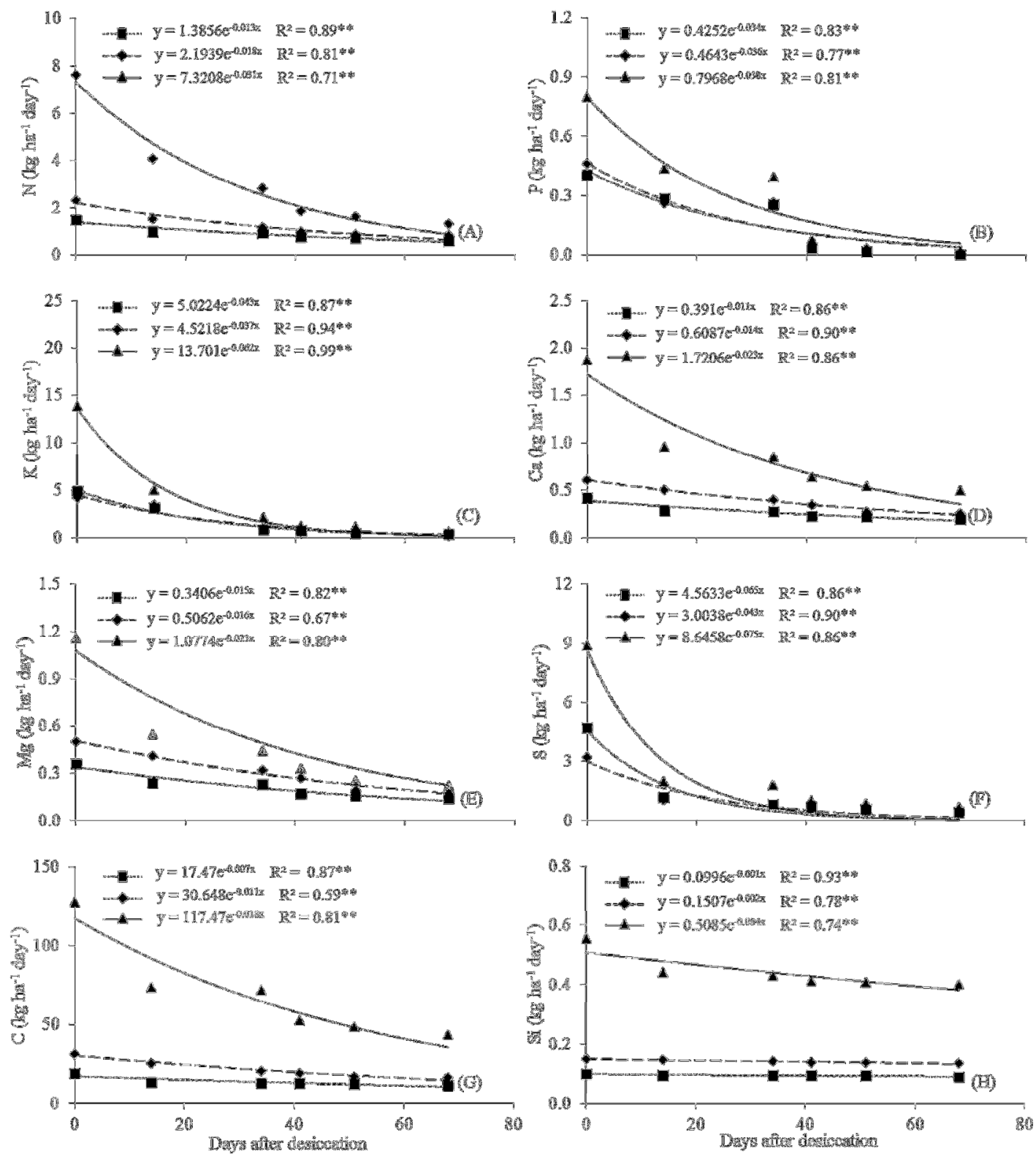

Figure 5. Daily release rate of $\mathrm{N}(\mathrm{A}), \mathrm{P}(\mathrm{B}), \mathrm{K}(\mathrm{C}), \mathrm{Ca}(\mathrm{D}), \mathrm{Mg}(\mathrm{E}), \mathrm{S}(\mathrm{F}) \mathrm{E} \mathrm{C}(\mathrm{G})$ and $\mathrm{Si}(\mathrm{H})$ of straws of pearl millet $(\mathbf{\Delta})$, palisade grass $(\bullet)$ and guinea grass $(\mathbf{\square})$, as a function of time after desiccation. ** Significant at $1 \%$ of probability by $\mathrm{F}$ test.

In the period between 0 and $14 \mathrm{DAD}$, the average daily release rates of $\mathrm{N}, \mathrm{P}, \mathrm{K}, \mathrm{Ca}, \mathrm{Mg}, \mathrm{S}$ and $\mathrm{C}$ of biomass reached intensities of $6.36,0.66,9,87$, $1.57,0.99,5.77$ and $112 \mathrm{~kg} \mathrm{ha}^{-1} \mathrm{day}^{-1}$ in pearl millet, $2.08,0.39,3.78,0.59,0.48,2.41$ and $31 \mathrm{~kg} \mathrm{ha}^{-1}$ day 1 in guinea grass, and 1.35, 0.36, 4.05, 0.39, 0.33, 3.22 and $18 \mathrm{~kg} \mathrm{ha}^{-1}$ day $^{-1}$ in palisade grass (Figure 5 ). The Si in biomass pearl millet, guinea grass and palisade grass had an almost constant release, with values in the initial period of $0.52,0.16$ and $0.11 \mathrm{~kg}$ $\mathrm{ha}^{-1}$ day $^{-1}$, and in the last period of 0.420 .14 and $0.10 \mathrm{~kg} \mathrm{ha}^{-1}$ day $^{-1}$, respectively.

The type, quantity and the speed at which each macroelement was released, regardless the type of vegetation, allow us to infer that to maximize the usage of these nutrients, the implementation of the 
economic culture should be performed after desiccation of cover crops. It is noteworthy that despite the biomass of pearl millet has lower persistence on the soil, its high production compensates the highest rate of decomposition, having always great amount of dry biomass of this species on the soil in the evaluated times. In addition, there was greater accumulation and release of macronutrients and $\mathrm{Si}$ of the biomass of pearl millet compared to other species. However, the guinea grass and palisade grass also produced, accumulated and released significant amounts of biomass and nutrients.

Considering the results of this study, we can highlight the pearl millet as the most appropriate for rotation in crop system under no-till, and the grass guinea or palisade grass for areas that adopt integrated crop-livestock system in regions of dry winter.

\section{CONCLUSIONS}

The pearl millet produced higher amounts of dry matter and accumulated more $\mathrm{N}, \mathrm{P}, \mathrm{K}, \mathrm{Ca}$, $\mathrm{Mg}, \mathrm{S}, \mathrm{C}$ and $\mathrm{Si}$ than guinea grass and palisade grass. $\mathrm{T}$ he maximum daily release rate of macronutrients occurred right after the handling of the biomass from the vegetal covers of the soil.

The rate of decomposition and release of nutrients and Si was higher in the biomass of pearl millet, compared to other vegetal covers.

In the course of time it was increased the $\mathrm{C} / \mathrm{N}$ ratio, cellulose and lignin and was decreased the $\mathrm{C} / \mathrm{Si}$ ration and the biomass decomposition rate. The $\mathrm{K}$ is the nutrient most quickly available to the soil, and Si has the lowest rate of release.

Plants with higher biomass production and lower $\mathrm{C} / \mathrm{Si}$ ratio are more interesting to use under no-till, by providing greater and more persistent ground cover.

\section{ACKNOWLEDGMENTS}

To São Paulo Research Foundation (FAPESP) for financial support (Registry number: 03/11739-5, 03/11738-9), and to the National Council for Scientific and Technological Development (CNPq), for providing scholarships to sencond and third author.

RESUMO: O objetivo deste trabalho foi avaliar a produção e persistência da biomassa de milheto (Pennisetum glaucum), capim colonião (Panicum maximum) e capim braquiária (Urochloa brizantha), bem como, a taxa de liberação dos macronutrientes e $\mathrm{Si}$ e as alterações na celulose, lignina, relação $\mathrm{C} / \mathrm{N}$ e $\mathrm{C} / \mathrm{Si}$. $\mathrm{O}$ delineamento experimental foi em blocos casualizados, com quatro repetições, em esquema fatorial constituído por três tipos de cobertura vegetal (milheto, capim colonião e capim-braquiária) e seis épocas de coleta $(0,14,34,41,51$ e 68 dias após a dessecação (DAD)). O milheto produziu maior quantidade de fitomassa e acumulou mais $\mathrm{N}, \mathrm{P}, \mathrm{K}, \mathrm{Ca}, \mathrm{Mg}, \mathrm{S}, \mathrm{C}$ e Si que o Panicum e Urochloa. A máxima taxa de liberação diária dos macronutrientes ocorreu logo após a dessecação da fitomassa das coberturas vegetais do solo. A taxa de decomposição e liberação de macronutrientes e Si foi maior na fitomassa do milheto, em relação às demais coberturas vegetais. Com o passar do tempo ocorreu aumento da relação $\mathrm{C} / \mathrm{N}$, teor de celulose e lignina e redução na relação C/Si e na taxa de decomposição da fitomassa. O K é o nutriente mais rapidamente disponibilizado ao solo, e o Si apresenta a menor taxa de liberação. Plantas com maior produção de fitomassa e com menor relação C/Si são mais interessantes para utilização no sistema plantio direto, por proporcionarem maior e mais persistente cobertura do solo.

PALAVRAS-CHAVE: Pennisetum glaucum. Panicum maximum. Urochloa brizantha. Persistência da palhada. Reciclagem de nutrientes.

\section{REFERENCES}

ALVARENGA, R. C.; CABEZAS, W. A. L.; CRUZ, J. C.; SANTANA, D. P. Plantas de cobertura de solo para sistema plantio direto. Informe Agropecuário, Belo Horizonte, v. 22, p. 25-36, 2001.

BARDUCCI, R. S.; COSTA, C.; CRUSCIOL, C. A. C.; BORGHI, E.; PUTAROV, T. C.; SARTI, L. M. N. Produção de Brachiaria brizantha e Panicum maximum com milho e adubação nitrogenada. Archivos de Zootecnia, Córdoba, v. 58, p. 211-222, 2009. http://dx.doi.org/10.4321/s0004-05922009000200006 
BERNARDES, T. G.; SILVEIRA, P. M.; MESQUISTA, M. A. M.; AGUIAR, R. A.; MESQUITA, G. M. Decomposição da biomassa e liberação de nutrientes dos capins braquiária e mombaça, em condições de cerrado. Pesquisa Agropecuária Tropical, Goiânia, v. 40, n. 3, p. 370-377, 2010.

http://dx.doi.org/10.5216/pat.v40i3.5584

BOER, C. A.; ASSIS, R. L.; SILVA, G. P.; BRAZ, A. J. B. P.; BARROSO, A. L. L.; CARGNELUTTI FILHO, A.; PIRES, F. R. Biomassa, decomposição e cobertura do solo ocasionada por resíduos culturais de três espécies vegetais na região centro-oeste. Revista Brasileira de Ciência do Solo, Viçosa, v. 32, p. 843-851, 2008.

BOER, C. A. ASSIS, R. L.; SILVA, G. P.; BRAZ, A. J. B. P.; BARROSO, A. L. L.; CARGNELUTTI FILHO, A.; PIRES, F. R. Ciclagem de nutrientes por plantas de cobertura na entressafra em um solo de cerrado. Pesquisa Agropecuária Brasileira, Brasília, v. 42, p. 1269-1276, 2007. http://dx.doi.org/10.1590/S0100204X2007000900008

BRAZ, A. J. B. P.; SILVEIRA, P. M.; KLIEMANN, H. J.; ZIMMERMANN, F. J. P. Acumulação de nutrientes em folhas de milheto e dos capins braquiária e Mombaça. Pesquisa Agropecuária Tropical, Goiânia, v. 34, p. 83-87, 2004.

COSTA, C. H. M.; CRUSCIOL, C. A. C.; SORATTO, R. P.; FERRARI NETO, J. Persistência e liberação de macronutrientes e silício da fitomassa de crotalária em função da fragmentação. Biosciencie Journal, Uberlândia, v. 28, n. 3, p. 384-394, 2012.

CRUSCIOL, C. A. C.; COTTICA, R. L.; LIMA, E. V.; ANDREOTTI, M.; MORO, E.; MARCON, E. Persistência de palhada e liberação de nutrientes do nabo forrageiro no plantio direto. Pesquisa Agropecuária Brasileira, v. 40, p. 161-168, 2005. http://dx.doi.org/10.1590/S0100-204X2005000200009

CRUSCIOL, C. A. C.; SORATTO, R. P. Nitrogen supply for cover crops and effects on peanut grown in succession under a no-till system. Agronomy Journal, Madison, v. 101, p. 40-46, 2009.

http://dx.doi.org/10.2134/agronj2008.0054

CRUSCIOL, C. A. C.; SORATTO, R. P. Nutrição e produtividade do amendoim em sucessão ao cultivo de plantas de cobertura no sistema plantio direto. Pesquisa Agropecuária Brasileira, Brasília, v. 42, p. 15531560, 2007. http://dx.doi.org/10.1590/S0100-204X2007001100006

CRUSCIOL, C. A. C.; MORO, E.; LIMA, E. V. ANDREOTTI, M. Taxas de decomposição e de liberação de macronutrientes da palhada de aveia preta em plantio direto. Bragantia, Campinas, v. 67, p. 481-489, 2008. http://dx.doi.org/10.1590/S0006-87052008000200024

FERNANDEZ, F. A.; BULL, L. T.; CORRÊA, J. C.; CRESPAM, D. R. Influência de silicato e calcário na decomposição de resíduos culturais e disponibilidade de nutrientes ao feijoeiro. Revista Brasileira de Ciência do Solo, Viçosa, v. 33, p. 935-945, 2009.

FERRARI NETO, J.; CRUSCIOL, C. A. C.; SORATTO, R. P.; COSTA, C. H. M. Consórcio de guandu-anão com milheto: persistência e liberação de macronutrientes e silício da fitomassa. Bragantia, Campinas, v. 71, p. 264-272, 2012. http://dx.doi.org/10.1590/S0006-87052012005000017

KORNDÖRFER, G. H. PEREIRA, H. S.; CAMARGO, M. S. Silicatos de cálcio e magnésio na agricultura. Uberlândia: GPSi - ICIAG - UFU, 2002. 23p. (Boletim Técnico).

LEITE, L. F. C.; FREITAS, R. C. A.; SAGRILO, S.; GALVÃO, S. R. S. Decomposição e liberação de nutrientes de resíduos vegetais depositados sobre Latossolo Amarelo no Cerrado Maranhense. Revista Ciência Agronômica, Fortaleza, v. 41, p. 29-35, 2010. 
MALAVOLTA, E., VITTI, G. C., OLIVEIRA, S. A. Avaliação do estado nutricional de plantas: princípios e aplicações. Piracicaba: Potafos, 1997. 308p.

MARSCHNER, H. Mineral nutrition of higher plants. Amsterdam, 2012. 684p.

MONQUERO, P. A., MILAN, B., SILVA, P. V.; HIRATA, A. C. S. INTERVALO DE DESSECAÇÃO DE ESPÉCIES DE COBERTURA DO SOLO ANTECEDENDO A SEMEADURA DA SOJA. Planta Daninha, Viçcosa, v. 28, n. 3, p. 561-573, 2010.

NUNES, U. R.; ANDRADE JÚNIOR, V. C.; SILVA, E. de B.; SANTOS, N. F.; COSTA, H. A. O.; FERREIRA, C. A. Produção de palhada de plantas de cobertura e rendimento do feijão em plantio direto. Pesquisa Agropecuária Brasileira, Brasília, v. 41, p. 943-948, 2006. http://dx.doi.org/10.1590/S0100204X2006000600007

PAUL, E. A.; CLARK, F. E. Soil microbiology and biochemistry. California, 1989. 340p.

PEGADO, C. M. A.; BARBOSA, L. J. N.; MENDES, J. E. M. F.; SOUTO, P. C; SOUTO, J. S. Decomposição superficial e subsuperficial de folhas de fava (Phaseolus lunatus L.) na região do Brejo da Paraíba, Brasil. Revista Caatinga, Mossoró, v. 21, n. 1, p. 218-223, 2008.

ROSA, S. R. A.; CASTRO, T. A. P.; OLIVEIRA, I. P. Análise de crescimento em braquiária nos sistemas de plantio solteiro e consórcio com leguminosas. Ciência Animal Brasileira, Goiânia, v. 5, n. 1, p. 9-17, 2004.

ROSA, S. R. A.; CASTRO, T. A. P.; OLIVEIRA, I. P. Análise de crescimento em capim-tanzânia nos sistemas de plantio solteiro e consórcio com leguminosas. Ciência Animal Brasileira, Goiânia, v. 8, n. 2, p. 251-260, 2007.

ROSOLEM, C. A.; CALONEGO, J. C.; FOLONI, J. S. S. Lixiviação de potássio da palhada de espécies de cobertura de solo de acordo com a quantidade de chuva aplicada. Revista Brasileira de Ciência do Solo, Viçosa, v. 27, p. 355-362, 2003.

SILVA, E. C.; MURAOKA, T.; BUZETTI, S.; VELOSO, M. E. C. TRIVELIN, P. C. O. Aproveitamento do nitrogênio $(15 \mathrm{~N})$ da crotalária e do milheto pelo milho sob plantio direto em Latossolo Vermelho de Cerrado. Ciência Rural, Santa Maria, v. 36, n. 3, 2006.

SORATTO, R. P.; CRUSCIOL, C. A. C.; COSTA, C. H. M.; FERRARI NETO, J.; CASTRO, G. S. A. Produção, decomposição e ciclagem de nutrientes em resíduos de crotalária e milheto, cultivados solteiros e consorciados. Pesquisa Agropecuária Brasileira, Brasília, v. 7, p. 1462-1470, 2012.

http://dx.doi.org/10.1590/S0100-204X2012001000008

TEDESCO, M. J.; WOLKWEISS, S. J.; BOHNEN, H. Análises de solo, plantas e outros materiais. Porto Alegre: Universidade Federal do Rio Grande do Sul, 1985. 188p. (Boletim técnico, 5).

THOMAS, R. J.; ASAKAWA, N. M. Decomposition of leaf litter from tropical forage grasses and legumes. Soil Biology and Biochemistry, Leicestershire, v. 25, p. 1351-1361, 1993. http://dx.doi.org/10.1016/00380717(93)90050-L

TORRES, J. L. R; PEREIRA, M. G.; FABIAN, A. J. Produção de fitomassa por plantas de cobertura e mineralização de seus resíduos em plantio direto. Pesquisa Agropecuária Brasileira, Brasília, v. 43, p. 421428, 2008. http://dx.doi.org/10.1590/S0100-204X2008000300018

VAN SOEST, P. J. Use of detergentes in the analysis of fibrous feeds. Journal of the association oficial analytical chemists, Washington, v. 46, p. 829-835, 1963. 
Phytomass decomposition and nutrients...

COSTA, C. H. M. et al.

VILELA, L.; MARTHA JUNIOR, G. B.; MACEDO, M. C. M.; MARCHÃO, R. L.; GUIMARÃES JÚNIOR, R.; PULROLNIK, K.; MACIEL, G. A. Sistemas de integração lavoura-pecuaria na região do Cerrado.

Pesquisa Agropecuária Brasileira, Brasília,v. 46, n. 10, p. 1127-1138, 2011. http://dx.doi.org/10.1590/S0100204X2011001000003 